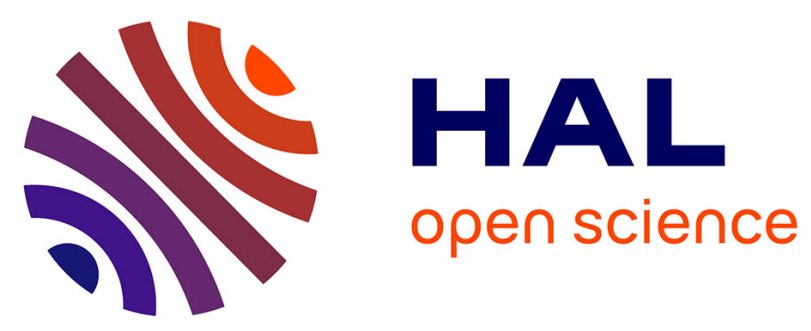

\title{
Antiproliferative and proapoptotic activity of CLM3, a novel multiple tyrosine kinase inhibitor, alone and in combination with $\mathrm{SN}-38$ on endothelial and cancer cells
}

Guido Bocci, Anna Fioravanti, Concettina La Motta, Paola Orlandi, Bastianina Canu, Teresa Di Desidero, Laura Mugnaini, Stefania Sartini, Sandro Cosconati, Rita Frati, et al.

\section{To cite this version:}

Guido Bocci, Anna Fioravanti, Concettina La Motta, Paola Orlandi, Bastianina Canu, et al.. Antiproliferative and proapoptotic activity of CLM3, a novel multiple tyrosine kinase inhibitor, alone and in combination with SN-38 on endothelial and cancer cells. Biochemical Pharmacology, 2011, 10.1016/j.bcp.2011.03.022 . hal-00693835

\section{HAL Id: hal-00693835 https://hal.science/hal-00693835}

Submitted on 3 May 2012

HAL is a multi-disciplinary open access archive for the deposit and dissemination of scientific research documents, whether they are published or not. The documents may come from teaching and research institutions in France or abroad, or from public or private research centers.
L'archive ouverte pluridisciplinaire HAL, est destinée au dépôt et à la diffusion de documents scientifiques de niveau recherche, publiés ou non, émanant des établissements d'enseignement et de recherche français ou étrangers, des laboratoires publics ou privés. 


\section{Accepted Manuscript}

Title: Antiproliferative and proapoptotic activity of CLM3, a novel multiple tyrosine kinase inhibitor, alone and in combination with SN-38 on endothelial and cancer cells

Authors: Guido Bocci, Anna Fioravanti, Concettina La Motta, Paola Orlandi, Bastianina Canu, Teresa Di Desidero, Laura Mugnaini, Stefania Sartini, Sandro Cosconati, Rita Frati, Alessandro Antonelli, Piero Berti, Paolo Miccoli, Federico Da Settimo, Romano Danesi

PII: S0006-2952(11)00209-7

DOI: doi:10.1016/j.bcp.2011.03.022

Reference: BCP 10862

To appear in: $\quad B C P$

Received date: $\quad$ 2-2-2011

Revised date: 22-3-2011

Accepted date: $\quad$ 25-3-2011

Please cite this article as: Bocci G, Fioravanti A, La Motta C, Orlandi P, Canu B, Di Desidero T, Mugnaini L, Sartini S, Cosconati S, Frati R, Antonelli A, Berti P, Miccoli P, Da Settimo F, Danesi R, Antiproliferative and proapoptotic activity of CLM3, a novel multiple tyrosine kinase inhibitor, alone and in combination with SN-38 on endothelial and cancer cells, Biochemical Pharmacology (2010), doi:10.1016/j.bcp.2011.03.022

This is a PDF file of an unedited manuscript that has been accepted for publication. As a service to our customers we are providing this early version of the manuscript. The manuscript will undergo copyediting, typesetting, and review of the resulting proof before it is published in its final form. Please note that during the production process errors may be discovered which could affect the content, and all legal disclaimers that apply to the journal pertain. 


\section{Antiproliferative and proapoptotic activity of CLM3, a novel multiple tyrosine kinase inhibitor, alone and in combination with SN-38 on endothelial and cancer cells}

Guido Bocci ${ }^{a *}$, Anna Fioravanti ${ }^{a}$, Concettina La Motta ${ }^{b}$, Paola Orlandi ${ }^{a}$, Bastianina Canu ${ }^{a}$, Teresa Di Desidero $^{a}$, Laura Mugnaini ${ }^{b}$, Stefania Sartini ${ }^{b}$, Sandro Cosconati ${ }^{c}$, Rita Frati ${ }^{a}$, Alessandro Antonelli $^{d}$, Piero Berti ${ }^{\mathrm{e}}$, Paolo Miccoli ${ }^{\mathrm{e}}$, Federico Da Settimo ${ }^{\mathrm{b}}$, Romano Danesi ${ }^{\mathrm{a}}$

aDivision of Pharmacology, Department of Internal Medicine, University of Pisa, Pisa, Italy; ${ }^{b}$ Department of Pharmaceutical Sciences, University of Pisa, Pisa, Italy; 'Department of Pharmaceutical Chemistry and Toxicology, University of Napoli "Federico II", Napoli, Italy,

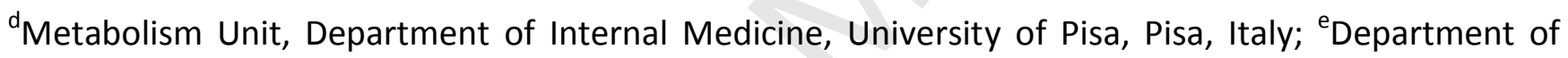
Surgery, University of Pisa, Pisa, Italy

\section{Running Title}

Antiangiogenic and antitumor activity of CLM3

\section{Key words}

CLM3; irinotecan; angiogenesis; synergism; tyrosine kinase inhibitor

\section{*Author for correspondence}

Guido Bocci, MD, PhD

Division of Pharmacology

Department of Internal Medicine

University of Pisa

Via Roma, 55

I-56126 Pisa, Italy

Phone: +39-050-2218750

Fax: +39-050-2218758

e-mail: guido.bocci@med.unipi.it 


\section{Abstract}

Aims. To demonstrate the antiproliferative and pro-apoptotic activity of the novel pyrazolopyrimidine derivative multiple tyrosine kinase inhibitor $\mathrm{CLM} 3$, alone and in combination with $\mathrm{SN}-38$ (the active metabolite of irinotecan), on endothelial and tumour cells and to show its mechanism of action.

Methods. Proliferation and apoptotic assays were performed on microvascular endothelial (HMVECd) and lung (A549) and thyroid cancer (8305C, TT) cell lines exposed to CLM3 and to the simultaneous combination with SN38 for 72h. Cell-based phospho-VEGFR-2, phospho-EGFR and phospho-RET inhibition assays were performed and ERK1/2 and Akt phosphorylation were quantified by ELISA kits. Cyclin D1 gene expression was performed with real-time PCR and cyclin D1 intracellular concentrations were measured by ELISA.

Results. A strong effect on antiproliferative and pro-apoptotic activity was found with the CLM3 on endothelial and cancer cells, synergistically enhanced by SN38. Phospho-VEGFR-2, phospho-EGFR and phospho-RET levels significantly decreased after CLM3 treatments in activated endothelial and cancer cells; ERK1/2 and Akt phosphorylation were significantly inhibited by lower concentrations of the pyrazolopyrimidine drug in endothelial cells if compared to cancer cells. Moreover, CLM3 treatment greatly inhibited the expression of the cyclin D1 gene in endothelial and cancer cells, decreasing the cyclin D1 protein intracellular concentration.

Conclusions. The pyrazolopyrimidine derivative CLM3 demonstrated a highly significant and promising antiproliferative and proapoptotic activity, alone and in combination with SN-38, for activated endothelial and cancer cell cells. These effects are mainly due to its inhibition of phosphorylation of VEGFR-2, EGFR and RET tyrosine kinases and their related signalling pathways. 
Tyrosine kinase inhibitors (TKIs) have significantly changed the perspectives of current cancer therapy. Understanding the mechanisms of normal and aberrant tyrosine kinase signalling and strategies to inhibit them in angiogenesis and cancer, further promote the development of novel agents $[1,2]$.

Vascular endothelial growth factors (VEGFs) and their respective family of receptor tyrosine kinases (VEGFRs) are key proteins modulating normal and pathological angiogenesis. Among VEGF receptors, VEGFR-2 is expressed in proliferating vascular endothelial cells of tumours as well as on circulating endothelial progenitor cells, and is related to multiple biological activities of VEGF, such as cell proliferation, migration and survival $[3,4]$. The EGFR is required for normal cellular proliferation, survival, adhesion, migration, and differentiation but a dysregulation of this pathway can lead to oncogenesis. Secretory loops may become established when the EGFR receptor is overexpressed and ligands are overproduced by either the tumor or the supporting stroma. EGFR signaling plays a key role in promoting the growth and survival of various types of solid tumors, including non-small cell lung cancer (NSCLC) and breast, gastric, prostate, thyroid and colorectal cancer [5]. The role of the RET oncogene in the development of medullary thyroid cancer (MTC) has been well described. RET signaling leads to activation of the RAS/mitogen-activated protein kinase and the phosphatidylinositol 3 'kinase/Akt pathways, having a key role in cell growth, differentiation, and survival. The activation of RET germline and somatic mutations has been identified as the primary cause of hereditary and sporadic MTC cases [6]. All of these examples illustrate that patients with cancer can significantly profit from the development of tyrosine kinase inhibitors, especially when an activated oncogene is proven to be the underlying cause for a given malignancy.

Based on these considerations, tyrosine kinases of growth factor receptors, such as EGFR and VEGFR-2, are highly attractive targets for the development of new specific anticancer agents [1]. Important preclinical evidence points out numerous cross talks between activated EGFR and VEGFR pathways in tumor biology and both pathways in tumor are upregulated due to the genetic profile, hypoxia and stress induced by anticancer strategies [7]. Therefore, the combination of inhibitors of both pathways is logical and may be more effective than blocking one or the other. This has been successfully investigated using agents with dual inhibition of both EGFR and VEGFR (e.g. ZD6474, 
BMS-690514 and AEE788) in vitro and in vivo preclinical settings of tumor angiogenesis [8-10]. Moreover, recent phase II/III clinical trials have confirmed an important clinical activity of ZD6474 in both NSCLC $[8,11]$ and on RET-mutated MTC $[12,13]$. However, all these new small molecules demonstrated a higher activity when administered in combinations with chemotherapeutic drugs [14, $15]$.

Researches aimed at the discovery of therapeutically useful inhibitors of TKIs have resulted in the identification of a variety of templates which, depending on the nature of attached substituents, provide selective inhibition both within and across different families of TKs. One of these privileged scaffold is the pyrazolo[3,4-d]pyrimidine nucleus, which proved to be a useful core for a variety of ATP-competitive TK inhibitors. Compounds belonging to this structural chemotype have been described as potent inhibitors of either cytoplasmatic TKs, such as cSrc and Abl [16-21] or receptor TKs, in particular EGFR [22].

The aim of the present study was to test the novel pyrazolopyrimidine derivative multitarget ATP-competitive tyrosine kinase inhibitor CLM3 on endothelial and tumour cells for future preclinical studies on tumor angiogenesis and NSLC and thyroid carcinoma models. 


\section{Materials and methods}

\subsection{Chemical synthesis of CLM3}

All the chemicals listed in this section were purchased from Sigma Chemical Co. (St. Louis, MO, USA). CLM3, (R)-1-phenethyl-N-(1-phenylethyl)-1H-pyrazolo[3,4-d]pyrimidin-4-amine (figure 1), was synthesized following a previously reported procedures [23]. Briefly, the commercially available 3amino-4-pyrazolecarbonitrile was alkylated with 2-bromoethylbenzene, in dimethylformamide and in the presence of $\mathrm{K}_{2} \mathrm{CO}_{3}$, to the corresponding 5-amino-1-phenethyl-1H-pyrazole-4-carbonitrile. Reaction with boiling formic acid provided the key intermediate 1-phenethyl-1H-pyrazolo[3,4d]pyrimidin-4(5H)-one. Treatment with phosphoryl trichloride gave the 4-chloro derivative, which led to the target inhibitor CLM3 by reaction with $(\mathrm{R})-(+)-1$-phenylethanamine in the presence of triethylamine.

\subsection{In vitro studies}

\subsubsection{Materials, drugs and cell lines}

Recombinant human epidermal growth factor (EGF), basic fibroblast growth factor (bFGF) and vascular endothelial growth factor (VEGF) were from PeproTechEC LTD (London, UK). Cell culture media MCDB131 and RPMI were purchased from Gibco BRL (Paisley, UK), quantitative real-time PCR reagents were from Applied Biosystems (Foster City, CA, USA), supplements and all other chemicals not listed in this section were obtained from Sigma Chemical Co. SN-38 (Pfizer, Groton, CT, USA), the active metabolite of irinotecan, and CLM3 were dissolved in a stock solution of $10 \mathrm{mM}$ in $100 \%$ DMSO for in vitro studies. The DMSO concentration in control's media was the one used to dilute the highest concentration of CLM3 or SN-38 in the same experiment.

Human dermal microvascular endothelial cells (HMVEC-d; Clonetics, San Diego, CA, USA) were maintained in MCDB131 culture medium supplemented with 10\% heat-inactivated FBS, L-glutamine 2 $\mathrm{mM}$, heparin 10 units $/ \mathrm{ml}$, EGF $10 \mathrm{ng} / \mathrm{ml}$ and bFGF $5 \mathrm{ng} / \mathrm{ml}$. The human undifferentiated thyroid cancer (with papillary component) cell line 8305C (DSMZ, Germany) and the human medullary thyroid cancer cell line TT (ATCC, Manassas, VA, USA) were maintained in 15\% FBS RPMI medium 
supplemented with L-glutamine $2 \mathrm{mM}$. The human lung carcinoma A549 cells (ATCC, Manassas, VA, USA) were maintained in RPMI culture medium supplemented with 10\% FBS, L-glutamine 2 mM.

\subsubsection{Antiproliferative and apoptosis assay}

In vitro chemosensitivity was tested on HMVEC-d, A549, 8305C and TT cell lines. Cells were plated in 24-well sterile plastic plates (1\% gelatin-coated for the endothelial cells) and treated for 24 and $72 \mathrm{~h}\left(1 \times 10^{3}\right.$ and $0.5 \times 10^{3}$ cells/well of endothelial or cancer cells, respectively, in $1 \mathrm{ml}$ of medium) with CLM3 (0.001-100 $\mu \mathrm{M})$ or with its vehicle alone. At the end of the experiment, cells were harvested with trypsin/EDTA and viable cells counted with a hemocytometer. Cell viability was assessed by trypan blue dye exclusion. The data are presented as the percentage of the vehicletreated cells. The concentration of drug that reduced cell proliferation by $50 \%\left(I C_{50}\right)$ vs. controls were calculated by nonlinear regression fit of the mean values of the data obtained in triplicate experiments (at least 9 wells for each concentration).

In order to quantify the degree of apoptosis induced by the drug treatments, HMVEC-d, A549 and $8305 \mathrm{C}$ cells were treated for $24 \mathrm{~h}$ and $72 \mathrm{~h}$ with CLM3 at three different concentrations: at a concentration corresponding to the experimental $I_{50}$ of cell proliferation, at higher and lower concentrations, and with vehicle alone. At the end of the incubation, cells were collected and the Cell Death Detection enzyme-linked immunosorbent assay (ELISA) Plus kit (Roche, Switzerland) were used. All experiments were repeated three time with a least three replicates per sample.

\subsubsection{In vitro assessment of synergism between CLM3 and SN-38 on endothelial and tumor cells}

The combination of CLM3 with SN-38 was explored on HMVEC-d and 8305C tumor cells with the simultaneous treatment schedule at a fixed molar concentration ratio of $1: 1$, as follows: simultaneous exposure of CLM3 (0.01-100 $\mu \mathrm{M})$ plus SN-38 $(0.01-100 \mu \mathrm{M})$ for $72 \mathrm{~h}$. To evaluate the level of interaction (synergistic, additive or antagonist) between CLM3 and SN-38 the Combination Index (Cl) method was followed [24]. Briefly, synergism or antagonism for CLM3 plus SN-38 was calculated on the basis of a multiple drug-effect equation, and quantitated by the $\mathrm{Cl}$ where $\mathrm{Cl}<1, \mathrm{Cl}=1$, and $\mathrm{Cl}>1$ indicates synergism, additive effect, and antagonism, respectively. Based on the classic isobologram for mutually exclusive effects, the $\mathrm{Cl}$ value was calculated as:

$C I=\left[(D)_{1} /\left(D_{x}\right)_{1}\right]+\left[(D)_{2} /\left(D_{x}\right)_{2}\right]$ 


\subsubsection{Cell-based phospho-VEGFR-2, phospho-EGFR and phospho-RET inhibition assay}

HMVEC-d ( $10^{5}$ cells/well), A549 and 8305 C cells $\left(5 \times 10^{4}\right.$ cells/well) were seeded and maintained with 1\% FBS medium. After $24 \mathrm{~h}$, cells were treated continuously for $72 \mathrm{~h}$ with CLM3 at a concentration around the experimental $I C_{50}$ of cell proliferation and at a higher and lower concentrations or with vehicle alone. The media were supplemented with rhVEGF $10 \mathrm{ng} / \mathrm{ml}$ or $\mathrm{rhEGF} 10 \mathrm{ng} / \mathrm{ml}$, depending on the assay to be performed. At the end of the experiment, the medium was removed and cells were rinsed with ice-cold PBS and directly lysed with $0.5 \mathrm{ml}$ ice-cold $1 \mathrm{X}$ lysis buffer (20 mM Tris pH7.5, 150 mM, 1 mM EDTA, 1 mM EGTA, 1\% triton X-100, $2.5 \mathrm{mM}$ sodium pyrophosphate, $1 \mathrm{mM} \beta-$ glycerolphosphate, $1 \mathrm{mM} \mathrm{Na}_{3} \mathrm{VO}_{4}, 1 \mathrm{\mu g} / \mathrm{ml}$ leupetin; Cell Signaling Technology ${ }^{\circledR}, \mathrm{MA}$, USA, cat.\#9803) and $1 \mathrm{mM}$ PMSF to each plate for $5 \mathrm{~min}$ at $4^{\circ} \mathrm{C}$. Lysates were collected and sonicated on ice for $10 \mathrm{~s}$. The samples were microcentrifuged for $10 \mathrm{~min}$ at $4^{\circ} \mathrm{C}$ and the supernatant was collected. Endothelial cell lysates were assayed as per manufacture’s instruction with PathScan ${ }^{\circledR}$ phospo-VEGFR-2 (Tyr1175) and Total VEGFR-2 sandwich ELISA kits (Cell Signaling Technology ${ }^{\circledR}$ ) and with PathScan ${ }^{\circledR}$ phospo-EGFR (Tyr1173) and Total EGFR sandwich ELISA kits (Cell Signaling Technology ${ }^{\circledR}$ ). A549 cell lysates were assayed with PathScan ${ }^{\circledR}$ phospo-EGFR (Tyr1173) and Total EGFR sandwich ELISA kits (Cell Signaling Technology ${ }^{\circledR}$ ) whereas $8305 \mathrm{C}$ cell lysates were tested with the PathScan ${ }^{\circledR}$ phospo-ret (panTyr) and Total Ret sandwich ELISA kits (Cell Signaling Technology ${ }^{\circledR}$ ). The optical density was determined using the microplate reader Multiskan Spectrum (Thermo Labsystems, Milan, Italy) set to $450 \mathrm{~nm}$. All experiments were repeated, independently, six times with at least 9 samples for each concentration. 


\subsubsection{ERK1/2 (pTpY185/187) and Akt $\left(p T^{308}{ }^{308}\right.$ ELISA assay}

HMVEC-d ( $10^{5}$ cells/well), A549 and $8305 \mathrm{C}\left(5 \times 10^{4}\right.$ cells/well), were treated for $72 \mathrm{~h}$ with CLM3 at a concentration around the experimental $I C_{50}$ of cell proliferation and at a higher and lower concentrations or with vehicle alone. To measure pERK1/2 and pAkt, at the end of the experiment the cells were harvested and immediately frozen with liquid nitrogen. Cells were then lysed as described above (section 2.2.4). Each sample was then assayed for human ERK1/2 and Akt phosporylation by the PhosphoDetect ${ }^{\oplus}$ ERK1/2 $\left(\mathrm{pThr}^{185} / \mathrm{pTyr}^{187}\right.$ ) ELISA Kit and the PhosphoDetect Akt $\left(\mathrm{pThr}^{308}\right.$ ) ELISA Kit (Calbiochem, USA), and normalized by total protein ERK1/2 and Akt concentration measured by ERK1/2 and Akt ELISA kits, respectively. The optical density was determined using the microplate reader Multiskan Spectrum set to $450 \mathrm{~nm}$. All experiments were repeated, independently, six times with at least 9 samples for each concentration.

\subsubsection{Quantification of cyclin D1 gene and protein expression in endothelial and tumor cells treated with CLM3}

To investigate the modulation of gene and protein of cyclin D1 by CLM3, HMVEC-d and 8305C cells were treated for $72 \mathrm{~h}$ with $\operatorname{CLM} 3(100,0.4,0.01 \mathrm{nM}$ and 100, 9.20, $0.1 \mu \mathrm{M}$, respectively) and vehicle alone.

To quantify cyclin D1 mRNA, RNA (1 $\mu \mathrm{g})$ was reverse transcribed as previously described [25] and the resulting cDNA was diluted (2:3) and then amplified by QRT-PCR with the Applied Biosystems 7900HT sequence detection system. Cyclin D1, validated primer was purchased from Applied Biosystems (Assay ID Hs00277039_m1). The PCR thermal cycling conditions and optimisation of primer concentrations were followed as per manufacturer's instructions. Amplifications were normalised to glyceraldehyde 3-phosphate dehydrogenase (GAPDH), and the quantitation of gene expression was performed using the $\Delta \Delta C_{\mathrm{t}}$ calculation, where $C_{\mathrm{t}}$ is the threshold cycle; the amount of target, normalised to the endogenous control and relative to the calibrator (vehicle-treated control cells), is given as $2^{-\Delta \Delta C}$. All experiments were repeated, independently, three times with at least 9 samples for each concentration.

To quantify the cyclin D1 protein, cells were directly lysed with $0.5 \mathrm{ml}$ ice-cold $1 \mathrm{X}$ lysis buffer as described above (section 2.2.4). Lysates were collected and sonicated on ice for $10 \mathrm{~s}$. The samples 
were microcentrifuged for $10 \mathrm{~min}$ at $4^{\circ} \mathrm{C}$ and the supernatant was collected. Endothelial and tumor cell lysates were assayed as per manufacture's instruction with the human Cyclin-D1 ELISA kit (USCN Life Science \& Technology Company, China, cat.\#E0585h). The optical density was determined using the microplate reader Multiskan Spectrum set to $450 \mathrm{~nm}$. The results were expressed as cyclin D1 ng per $\mathrm{mg}$ of total protein. All experiments were repeated, independently, six times with at least 9 samples for each concentration.

\subsection{Statistical analysis}

The results (mean \pm S.E.M.) of all the experiments were subjected to analysis of variance between groups (ANOVA), followed by the Student-Newman-Keuls test. The level of significance was set at $P<0.05$. 


\section{Results}

\subsection{CLM3 inhibits endothelial and tumour cell proliferation in a time- and concentration-dependent} manner

CLM3 has shown a significant time- and concentration-dependent inhibitory activity on human cancer and endothelial cell proliferation after 24 (figure 2A) and 72 hours (figure 2B) of exposure. The microvascular endothelial cell line HMVEC-d was sensitive to low concentrations of CLM3. Indeed, the maximum effect of CLM3 was obtained in these endothelial cells $\left(\mathrm{IC}_{50} \mathrm{~S} 2.08 \pm 0.77 \mathrm{nM}\right.$ and $0.40 \pm 0.22$ $\mathrm{nM}$ for $24 \mathrm{~h}$ and $72 \mathrm{~h}$, respectively). Moreover, CLM3 showed also a time- and concentrationdependent effect on $A 549$ cell line as outlined by the calculated $I_{50} \mathrm{~S}$ after $24 \mathrm{~h}$ and $72 \mathrm{~h}$ exposures (34.15 $\pm 8.9 \mu \mathrm{M}$ and $4.70 \pm 1.80 \mu \mathrm{M}$, respectively) that, however, resulted much higher than those found in endothelial cells. Interestingly, also thyroid cancer cells responded to CLM3 (figure 2B); furthermore, the undifferentiated thyroid cancer $8305 \mathrm{C}$ cell line proliferation was inhibited after $72 \mathrm{~h}$ $\left(I C_{50} 9.20 \pm 5.06 \mu \mathrm{M}\right)$ at lower concentrations if compared to the medullary thyroid cancer TT cells $\left({ }^{2} C_{50}\right.$ $26.93 \pm 7.60 \mu \mathrm{M})$.

\subsection{Induction of apoptosis by CLM3 in endothelial and cancer cells}

The extent of DNA fragmentation was dependent on the concentration of the experimental drug. In particular, the presence of chromatin fragments was detectable after $24 \mathrm{~h}$ and $72 \mathrm{~h}$ in a concentration-dependent manner for CLM3 (figure 3). Figure 3A and 3B show a significant proapoptotic activity of CLM3 already after $24 \mathrm{~h}$ of exposure in endothelial cell and cancer cells, respectively. As shown in figure $\mathbf{3 C}$, after $72 \mathrm{~h}$ of treatment with $\mathrm{CLM} 3$ a significant percentage of apoptotic HMVEC-d endothelial cells in the treated samples were found when compared to controls. Furthermore, the same pro-apoptotic effects of CLM3 were observed also in both cancer cell lines $8305 C$ and A549 (figure 3D and E, respectively) even though at higher concentrations.

\subsection{Synergistic effect of CLM3 and SN-38 on HMVEC-d and 8305C cell proliferation}

Simultaneous and continuous exposure of HMVEC-d and 8305C cells to different concentrations of CLM3 and SN-38 for $72 \mathrm{~h}$ showed a strong synergism ( $\mathrm{Cl} 1$ and $\mathrm{DRI}>1$, figure 4 and 
table 1). Synergism corresponding to $\mathrm{Cl}<1$ always yielded a favorable $\mathrm{DRI}>1$ for both drugs (table 1 ). Figure 4A shows the $\mathrm{Cl} /$ Fraction affected ( $\mathrm{Fa}$ ) curve of HMVEC-d cells exposed to CLM3 and SN-38 for $72 \mathrm{~h}$ with the simultaneous schedule of treatment. Furthermore, the simultaneous treatments of CLM3 and SN-38 for $72 \mathrm{~h}$ were synergistically active on undifferentiated thyroid cancer $8305 \mathrm{C}$ cell proliferation, as shown by the $\mathrm{Cl} / \mathrm{Fa}$ curve in figure 4B.

\subsection{Inhibition of VEGFR-2, EGFR and RET phosphorylation in endothelial and cancer cells by CLM3}

After exposure to CLM3 at different concentrations, the amount of both phosphorylated forms of VEGFR-2 and EGFR in HMVEC-d cell lysates (figure 5A) was significantly reduced. Moreover, the ratio of phosphorylated/nonphosphorylated RET protein of treated cells was significantly decreased in 8305 C cells (figure 5B).

\subsection{Inhibition of ERK1/2 and Akt phosphorylation in endothelial and cancer cells by CLM3}

After exposure to CLM3, the quantity of the active, phosphorylated form of ERK1/2 and Akt in HMVEC-d cells (figure 6A) was significantly reduced in a concentration-dependent manner. The ratio of phosphorylated/nonphosphorylated ERK1/2 and Akt proteins of treated cells appeared significantly decreased also in $8305 \mathrm{C}$ and A549 cells, respectively (figure 6B and C). Interestingly, the significant inhibition of phosphorylation of both ERK1/2 and Akt in the endothelial cell lines was obtained at much lower concentrations if compared to cancer cells.

\subsection{CLM3 inhibits cyclin D1 gene expression and decreases cyclin D1 protein levels in endothelial} and cancer cells

In order to study the effect of CLM3 treatment to the variation of cyclin D1 expression, the gene expression of this cell cycle protein was quantified in the endothelial HMVEC-d and 8305C cell lines exposed to different drug concentrations. The figure 7A and B showed the concentrationdependent and significant inhibition of the gene expression of cyclin D1 in HMVEC-d and 8305C cells, respectively, by CLM3.

Based on these findings we measured the intracellular levels of cyclin D1 protein in treated and untreated (vehicle only) cells. Lower cyclin D1 concentrations were found in endothelial cells (figure 7A) exposed to CLM3 if compared with the ones exposed to vehicle. Of note, the same 
1

2

3

4 5

6

7

8

9

10

11

12

13

14

15

16

17

18

19

20

21

22

23

24

25

26

27

28

29

30

31

32

33

34

35

36

37

38

39

40

41

42

43

44

45

46

47

48

49

50

51

52

53

54

55

56

57

58

59

60

61

62

63

64

65 concentration-dependent cyclin D1 decrease was obtained by CLM3 in 8305C cancer cells (figure 7B)

at

much

higher

concentrations. 


\section{Discussion}

Multiple kinases are deeply involved in tumor development and angiogenesis and their inhibition has been developed as a systemic treatment strategy for cancer [1]. Thus, the most targeted area of developing antineoplastic drugs is through the inhibition of EGFR and VEGFR signaling. This therapeutic strategy in oncology has been successful using biologics, cetuximab [26] and ramucirumab [27], as well as small molecules such as gefitinib [28], vandetanib [8], sorafenib, sunitinib [1]. As an example, the direct inhibition of VEGFR-2 tyrosine kinase activity with a small molecule (sorafenib and sunitinib) has been recently approved by the FDA for the treatment of renal cell cancer. Moreover, among newly synthesized tyrosine kinase inhibitors, a great interest have been received the pyrazolopyrimidine derivatives [29]. A considerable effort has been made over the last few years to deepen the structure-activity relationships of this class of inhibitors. Thus, a wide range of substituents, flexible or rigid, linear or cyclic, neutral or basic, has been inserted in the positions N1, N2, C3, C4 and/or C6 of the heterocyclic nucleus, in order to modulate potency and selectivity. An excellent example of lead optimization is represented by our 1-phenylethyl-pyrazolo[3,4- $d$ ]pyrimidine derivative, named CLM3, that has shown an in vivo antitumor activity in papillary dedifferentiated thyroid cancer model; indeed, CLM3 was administered in nude mice at the dose of $40 \mathrm{mg} / \mathrm{kg} / \mathrm{day}$ for more than 20 days and it inhibited significantly the tumor growth without showing any appreciable toxicity, as demonstrated from weights of mice [30]. In this report, we identify, for the first time, the pyrazolo[3,4- $d$ ]pyrimidine CLM3 as a novel, multiple signal transduction inhibitor (EGFR, VEGFR-2 and RET) that has antiproliferative and proapoptotic activity on endothelial and cancer cells. Antiangiogenic tyrosine kinase inhibitors have been subdivided in three different types: i) type I kinase inhibitors that recognize the active conformation of a kinase and competitively bind to the ATP-binding site; ii) type II kinase inhibitors that recognize the inactive conformation of a kinase, occupying the hydrophobic pocket which is directly adjacent to the ATP-binding site; and finally iii) type III kinase inhibitors that covalently bind to cysteines at specific site of the kinase [1]. Due to structural analogy with type I kinase inhibitors, like vandetanib, it is reasonably plausible to include CLM3 in this class of compounds. From a preclinical point of view, the synthesis and study of this new inhibitor of tyrosine kinases had a considerable success. In fact, this new compound has shown a 
significant efficacy against proliferation of endothelial and cancer cells, inhibiting the phosphorylation of VEGFR-2, EGFR and RET in our cellular models. Moreover, there are recent experimental evidences of autocrine activation of EGFRs and VEGFRs in papillary thyroid cancer cell lines (eg. TPC1 cells) [31] that suggest a particular rationale for the use of tyrosine kinase inhibitors with dual modes of action, such as vandetanib [32,33] and sunitinib [34] for the therapeutic treatment of this kind of disease. Furthermore, these compounds can also effectively act through the inhibition of tumor angiogenesis, a key process of the neoplastic growth in thyroid cancers [35]. Actually, the novel inhibitor CLM3 displayed significant antiproliferative and pro-apoptotic effects on endothelial and cancer cells, with a mechanism mediated by the inhibition of phosphorylation of ERK1/2 and Akt, respectively. In this, CLM3 shows a similar behaviour to other small molecules that inhibit EGFR and VEGFR-2, such as vandetanib [36, 37], or VEGFR-2 such as axitinib [38,39], which have been shown to inhibit in vitro both ERK1/2 and Akt phosphorylation in endothelial and cancer cells.

CLM3 has comparable activities also to other inhibitors of EGF-R or VEGF-R tyrosine kinases, such as gefinitib, vatalanib and pazopanib, in inhibiting both the phosphorylation of the receptors in cell-based assays and the in vitro EGF/VEGF-stimulated proliferation of endothelial and cancer cells. Indeed, pazopanib potently inhibited VEGF-induced phosphorylation of VEGFR-2 in HUVEC with an IC50 of $\sim 8 \mathrm{nM}$ as determined by Western blotting. In addition, in cellular assays pazopanib inhibited proliferation of VEGF-driven HUVEC with an IC50 of $21 \mathrm{nM}$, with a 35-fold selectivity over bFGFinduced HUVEC proliferation. The inhibition of VEGF-induced HUVEC proliferation was greater than 1400-fold more selective than that observed for inhibition of proliferation of a variety of tumor cells and greater than 48-fold for fibroblasts [40]. In cell-based assays, vatalanib inhibits VEGF-induced VEGFR-2 phosphorylation with IC50 values of $17 \mathrm{nM}$ (endothelial cells) and $34 \mathrm{nM}$ (CHO cells transfected with VEGFR-2). The compound inhibited HUVEC proliferation, migration, and survival with IC50 values of $7.1,58$, and $<10 \mathrm{nM}$, respectively, but did not inhibit the proliferation of A431 or DU145 cells even at concentrations of up to $1 \mu \mathrm{M}$ [41]. The antitumor activity of vatalanib has been also investigated in vitro on anaplastic thyroid carcinoma (ATC) cell lines and it has been found that vatalanib did not affect the proliferation of these cell lines [42].

Gefitinib was the first small molecule inhibitor of EGFR to enter clinical trials. In preclinical studies, gefitinib completely blocked EGF-stimulated EGFR phosphorylation at $0.16 \mu \mathrm{M}$ in Du145 (prostate) and A549 (lung) cells, whereas complete inhibition was achieved at $0.8 \mu \mathrm{M}$ in $\mathrm{KB}$ (oral 
squamous) and HT29 (colon) tumor cells [43]. Moreover, gefitinib was a potent and selective inhibitor of EGF-stimulated KB tumor cell growth in vitro. Selectivity was demonstrated by the $>100$-fold difference in IC50 for cells grown in the presence (IC50, $0.054 \mu \mathrm{M})$ or absence (IC50, $8.8 \mu \mathrm{M})$ of EGF. Similarly, gefitinib selectively inhibited EGF-stimulated growth of HUVECs (IC50, 0.03-0.1 $\mu \mathrm{M}$ ) compared with FGF- or VEGF-stimulated growth (IC50, 1-3 $\mu \mathrm{M})$ [43].

Regulated progression through the cell cycle requires sequential expression of a family of proteins called cyclins. Induction of the proto-oncogene cyclin D1, and its binding to CDK4 or CDK6, is a rate limiting event during cell-cycle progression through G1 phase [44]. When cancer cells are cultured as multicellular aggregates, cyclin D1 is induced through a serum-dependent EGFR activating pathway, triggering cell proliferation. The expression of cyclin D1 required both EGFR-mediated ERK and Akt activation [45]. Blocking EGFR function inhibits the expression of cyclin D1 and proliferation [46]. Indeed, CLM3, after inhibiting EGFR and VEGFR-2 phosphorylation and consequently ERK and Akt activities, determines the suppression of cyclin D1 both at gene expression and protein levels. It has been previously demonstrated that in non-transformed cells, the cyclin D1 gene senses the mitogenic potential of the microenvironment because its induction requires coordinated signaling from the extracellular matrix and soluble growth factors [44]. Activators of cyclin D1 gene transcription are mitogenic growth factors, and, it has been described that also nuclear EGFR is able to bind the cyclin D1 promoter, promoting the gene transcription [47]. Interestingly, also vandetanib inhibited cell proliferation in a dose-dependent manner, by blocking cell progression at the G0-G1 stage, through the downregulation of expression of cyclin D1 and cyclin E [37].

The association of CLM3 with SN-38, the active metabolite of irinotecan, showed a marked synergistic effect on endothelial and cancer cells, placing our compound on the same level as those currently being tested for combination chemotherapy regimens, such as vandetanib [48], pazopanib [49] and axitinib [39]. In order to improve the antineoplastic activity of CLM3, we presently investigated the effects of CLM3 in combination with SN-38 in EGFR and VEGFR-2 expressing human endothelial cell line HMVEC-d and in EGFR and RET expressing human thyroid cancer cell 8305C [50]. CLM3 synergistically decreased cell proliferation when used in combination with SN-38, suggesting that incorporating chemotherapy (SN-38) with an anti-EGFR, VEGFR and RET strategy (CLM3) may be more effective in treating patients with thyroid cancer than either approach alone [30]. Furthermore, 


\section{Acknowledgements}

The authors thank Prof. Franco Bocci. The present study has been supported by a grant of MIUR (Italian Ministry for the University and Research) PRIN (Progetti di Interesse Nazionale) 2007 to G.B. There was no role of MIUR in study design; in the collection, analysis and interpretation of data; in the writing of the report; and in the decision to submit the paper for publication. 


\section{Figure legends}

Figure 1. Chemical structure of the (R)-1-phenethyl-N-(1-phenylethyl)-1H-pyrazolo[3,4- $d$ ]pyrimidin-4amine CLM3.

Figure 2. Effect of $\mathrm{CLM} 3$ on in vitro cell proliferation after $24 \mathrm{~h}(\mathbf{A})$ and $72 \mathrm{~h}(\mathbf{B})$ exposures. The antiproliferative effects of the drugs were studied using continuous exposures on HMVEC-d, A549, TT and $8305 \mathrm{C}$ cell lines. Symbols and bars, mean values $\pm \mathrm{SE}$, respectively. $* P<0.05$ vs. vehicle-treated controls. $I C_{50}$, the concentration of drug that reduced cell proliferation by $50 \%$.

Figure 3. Pro-apoptotic effects of CLM3 on proliferating HMVEC-d (A) and A549 (B) cells treated for 24 h. The apoptotic effects were also tested after $72 \mathrm{~h}$ on HMVEC-d (C), 8305C (D) and A549 (E) cells. Columns and bars, mean values $\pm \mathrm{SE}$, respectively. ${ }^{*} P<0.05$ or $P<0.01$ vs. vehicle-treated controls. Control- stands for the negative control of the ELISA kit.

Figure 4. Combination Index/Fraction affected curves of HMVEC-d (A), and 8305C (B) cell proliferation inhibition by simultaneous combination of CLM3 and SN-38, the active metabolite of irinotecan. The symbols represents the combination index values (synergism $\mathrm{Cl}<1$ ) per the fraction of cells affected by the combination.

Figure 5. Inhibition of VEGFR-2 and EGFR phosphorylation by CLM3 in HMVEC-d cells after $72 \mathrm{~h}$ of treatment (A). pVEGFR-2 and pEGFR concentrations were measured by ELISA kits and they were normalized to total VEGFR-2 and EGFR protein concentration, respectively. Inhibition of RET phosphorylation by CLM3 in $8305 \mathrm{C}$ cells after $72 \mathrm{~h}$ of treatment (B). pRET concentrations were measured by an ELISA kit and they were normalized to total RET protein concentration. Columns and bars, mean values $\pm S E$, respectively. ${ }^{*} P<0.05$ vs. vehicle-treated controls.

Figure 6. Inhibition of Akt $\left(\mathrm{pThr}^{308}\right)$ and ERK1/2 $\left(\mathrm{pThr}^{185} / \mathrm{pTyr}^{187}\right)$ phosphorylation by CLM3 in HMVEC$\mathrm{d}(\mathrm{A}), 8305 \mathrm{C}$ (B) and A549 (C) cells after $72 \mathrm{~h}$ of treatment. pAkt and pERK1/2 concentrations were 
1

2

3

measured by ELISA kits and they were normalized to total Akt and ERK1/2 protein concentration, respectively. Columns and bars, mean values \pm SE, respectively. ${ }^{*} P<0.05$ vs. vehicle-treated controls.

Figure 7. Cyclin D1 gene expression and cyclin D1 protein concentrations in HMVEC-d (A) and 8305C (B) cells exposed to CLM3 or with vehicle alone for 72 h.Columns and bars, mean values $\pm \mathrm{SE}$, respectively. ${ }^{*} P<0.05$ vs. vehicle-treated controls. 
References

[1] Gotink KJ, Verheul HM. Anti-angiogenic tyrosine kinase inhibitors: what is their mechanism of action? Angiogenesis 2010;13:1-14.

[2] Pytel D, Sliwinski T, Poplawski T, Ferriola D, Majsterek I. Tyrosine kinase blockers: new hope for successful cancer therapy. Anticancer Agents Med Chem 2009;9:66-76.

[3] Ferrara N. Vascular endothelial growth factor. Arterioscler Thromb Vasc Biol 2009;29:789-91.

[4] Ivy SP, Wick JY, Kaufman BM. An overview of small-molecule inhibitors of VEGFR signaling. Nat Rev Clin Oncol 2009;6:569-79.

[5] Yoshida T, Zhang G, Haura EB. Targeting epidermal growth factor receptor: central signaling kinase in lung cancer. Biochem Pharmacol 2010;80:613-23.

[6] Ball DW. Medullary thyroid cancer: monitoring and therapy. Endocrinol Metab Clin North Am 2007;36:823-37, viii.

[7] Hoekman K, Van Cruijsen H, Giaccone G. The EGF (R) and VEGF (R) pathways as combined targets for anti-angiogenesis trials in cancer therapy. In: Marmé D, Fusenig N, editors. Tumor Angiogenesis Basic Mechanisms and Cancer Therapy. Berlin: Springer, 2007 p. 707-15.

[8] Morabito A, Piccirillo MC, Falasconi F, De Feo G, Del Giudice A, Bryce J, et al. Vandetanib (ZD6474), a dual inhibitor of vascular endothelial growth factor receptor (VEGFR) and epidermal growth factor receptor (EGFR) tyrosine kinases: current status and future directions. Oncologist 2009;14:378-90.

[9] Okamoto K, Neureiter D, Alinger B, Meissnitzer M, Sass G, Schmitz V, et al. The dual EGF/VEGF receptor tyrosine kinase inhibitor AEE788 inhibits growth of human hepatocellular carcinoma xenografts in nude mice. Int J Oncol 2008;33:733-42.

[10] Loriot Y, Mordant P, Dorvault N, De la motte Rouge T, Bourhis J, Soria JC, et al. BMS-690514, a VEGFR and EGFR tyrosine kinase inhibitor, shows anti-tumoural activity on non-small-cell lung cancer xenografts and induces sequence-dependent synergistic effect with radiation. $\mathrm{Br} \mathrm{J}$ Cancer 2010;103:347-53. 
[11] Pennell NA, Lynch TJ, Jr. Combined inhibition of the VEGFR and EGFR signaling pathways in the treatment of NSCLC. Oncologist 2009;14:399-411.

[12] Robinson BG, Paz-Ares L, Krebs A, Vasselli J, Haddad R. Vandetanib (100 mg) in patients with locally advanced or metastatic hereditary medullary thyroid cancer. J Clin Endocrinol Metab 2010;95:2664-71.

[13] Wells SA, Jr., Gosnell JE, Gagel RF, Moley J, Pfister D, Sosa JA, et al. Vandetanib for the treatment of patients with locally advanced or metastatic hereditary medullary thyroid cancer. J Clin Oncol 2010;28:767-72.

[14] Herbst RS, Sun Y, Eberhardt WE, Germonpre P, Saijo N, Zhou C, et al. Vandetanib plus docetaxel versus docetaxel as second-line treatment for patients with advanced non-small-cell lung cancer (ZODIAC): a double-blind, randomised, phase 3 trial. Lancet Oncol 2010;11:619-26.

[15] Kerbel RS. Antiangiogenic therapy: a universal chemosensitization strategy for cancer? Science 2006;312:1171-5.

[16] Rossi A, Schenone S, Angelucci A, Cozzi M, Caracciolo V, Pentimalli F, et al. New pyrazolo-[3,4d]-pyrimidine derivative Src kinase inhibitors lead to cell cycle arrest and tumor growth reduction of human medulloblastoma cells. FASEB J 2010;24:2881-92.

[17] Carraro F, Pucci A, Naldini A, Schenone S, Bruno O, Ranise A, et al. Pyrazolo[3,4-d]pyrimidines endowed with antiproliferative activity on ductal infiltrating carcinoma cells. J Med Chem 2004;47:1595-8.

[18] Santucci MA, Corradi V, Mancini M, Manetti F, Radi M, Schenone S, et al. C6-unsubstituted pyrazolo[3,4-d]pyrimidines are dual Src/Abl inhibitors effective against imatinib mesylate resistant chronic myeloid leukemia cell lines. ChemMedChem 2009;4:118-26.

[19] Carraro F, Naldini A, Pucci A, Locatelli GA, Maga G, Schenone S, et al. Pyrazolo[3,4d]pyrimidines as potent antiproliferative and proapoptotic agents toward A431 and 8701-BC cells in culture via inhibition of c-Src phosphorylation. J Med Chem 2006;49:1549-61.

[20] Schenone S, Bruno O, Ranise A, Bondavalli F, Brullo C, Fossa P, et al. New pyrazolo[3,4d]pyrimidines endowed with A431 antiproliferative activity and inhibitory properties of Src phosphorylation. Bioorg Med Chem Lett 2004;14:2511-7. 
[21] Navarra M, Celano M, Maiuolo J, Schenone S, Botta M, Angelucci A, et al. Antiproliferative and pro-apoptotic effects afforded by novel Src-kinase inhibitors in human neuroblastoma cells. BMC Cancer 2010;10:602.

[22] Traxler P, Bold G, Frei J, Lang M, Lydon N, Mett H, et al. Use of a pharmacophore model for the design of EGF-R tyrosine kinase inhibitors: 4-(phenylamino)pyrazolo[3,4-d]pyrimidines. J Med Chem 1997;40:3601-16.

[23] Bocci G, Da Settimo F, Del Tacca M, Fioravanti A, La Motta C, Martini C, et al. Preparation of $2 H$-pyrazolo[3,4-d]pyrimidine derivatives as inhibitors of protein tyrosine kinase receptor. Ital. Appl. IT2007RM0480, 2007.

[24] Chou TC. Theoretical basis, experimental design, and computerized simulation of synergism and antagonism in drug combination studies. Pharmacol Rev 2006;58:621-81.

[25] Bocci G, Fioravanti A, Orlandi P, Bernardini N, Collecchi P, Del Tacca M, et al. Fluvastatin synergistically enhances the antiproliferative effect of gemcitabine in human pancreatic cancer MIAPaCa-2 cells. Br J Cancer 2005;93:319-30.

[26] Frampton JE. Cetuximab: a review of its use in squamous cell carcinoma of the head and neck. Drugs 2010;70:1987-2010.

[27] Spratlin J. Ramucirumab (IMC-1121B): Monoclonal Antibody Inhibition of Vascular Endothelial Growth Factor Receptor-2. Curr Oncol Rep 2011;13(2):97-102.

[28] Gupta A, Raina V. Gefitinib. J Cancer Res Ther 2010;6:249-54.

[29] Dreassi E, Zizzari AT, Falchi F, Schenone S, Santucci A, Maga G, et al. Determination of permeability and lipophilicity of pyrazolo-pyrimidine tyrosine kinase inhibitors and correlation with biological data. Eur J Med Chem 2009;44:3712-7.

[30] Antonelli A, Bocci G, La Motta C, Ferrari SM, Fallahi P, Fioravanti A, et al. Novel Pyrazolopyrimidine Derivatives as Tyrosine Kinase Inhibitors with Antitumoral Activity in Vitro and in Vivo in Papillary Dedifferentiated Thyroid Cancer. J Clin Endocrinol Metab 2011;96:E288-E96.

[31] Hoffmann S, Burchert A, Wunderlich A, Wang Y, Lingelbach S, Hofbauer LC, et al. Differential effects of cetuximab and AEE 788 on epidermal growth factor receptor (EGF-R) and vascular endothelial growth factor receptor (VEGF-R) in thyroid cancer cell lines. Endocrine 2007;31:105-13. 
[32] Carlomagno F, Guida T, Anaganti S, Provitera L, Kjaer S, McDonald NQ, et al. Identification of tyrosine 806 as a molecular determinant of RET kinase sensitivity to ZD6474. Endocr Relat Cancer 2009;16:233-41.

[33] Carlomagno F, Vitagliano D, Guida T, Ciardiello F, Tortora G, Vecchio G, et al. ZD6474, an orally available inhibitor of KDR tyrosine kinase activity, efficiently blocks oncogenic RET kinases. Cancer Res 2002;62:7284-90.

[34] Kim DW, Jo YS, Jung HS, Chung HK, Song JH, Park KC, et al. An orally administered multitarget tyrosine kinase inhibitor, SU11248, is a novel potent inhibitor of thyroid oncogenic RET/papillary thyroid cancer kinases. J Clin Endocrinol Metab 2006;91:4070-6.

[35] Mitchell JC, Parangi S. Angiogenesis in benign and malignant thyroid disease. Thyroid 2005;15:494-510.

[36] Sarkar S, Mazumdar A, Dash R, Sarkar D, Fisher PB, Mandal M. ZD6474 enhances paclitaxel antiproliferative and apoptotic effects in breast carcinoma cells. J Cell Physiol 2011;226:37584.

[37] Sarkar S, Mazumdar A, Dash R, Sarkar D, Fisher PB, Mandal M. ZD6474, a dual tyrosine kinase inhibitor of EGFR and VEGFR-2, inhibits MAPK/ERK and AKT/PI3-K and induces apoptosis in breast cancer cells. Cancer Biol Ther 2010;9:592-603.

[38] Hu-Lowe DD, Zou HY, Grazzini ML, Hallin ME, Wickman GR, Amundson K, et al. Nonclinical antiangiogenesis and antitumor activities of axitinib (AG-013736), an oral, potent, and selective inhibitor of vascular endothelial growth factor receptor tyrosine kinases 1, 2, 3. Clin Cancer Res 2008;14:7272-83.

[39] Canu B, Fioravanti A, Orlandi P, Di Desidero T, Alì G, Fontanini G, et al. Irinotecan synergistically enhances the antiproliferative and pro-apoptotic effects of axitinib in vitro and improves its anticancer activity in vivo. Neoplasia 2011;13:217-29.

[40] Harris P, Stafford J. Discovery of pazopanib: a pan vascular endothelial growth factor kinase inhibitor. In: Li R, Stafford J, editors. Kinase Inhibitor Drugs. Haboken, New Jersey: John Wiley \& Sons, Inc., 2009.

[41] Matthews D, Gerritsen M. Angiokinase Inhibitors. Targeting Protein Kinases for Cancer Therapy. Hoboken, New Jersey: John Wiley \& Sons, Inc., 2010. 
[42] Kim S, Yazici YD, Barber SE, Jasser SA, Mandal M, Bekele BN, et al. Growth inhibition of orthotopic anaplastic thyroid carcinoma xenografts in nude mice by PTK787/ZK222584 and CPT-11. Head Neck 2006;28:389-99.

[43] Wakeling AE, Guy SP, Woodburn JR, Ashton SE, Curry BJ, Barker AJ, et al. ZD1839 (Iressa): an orally active inhibitor of epidermal growth factor signaling with potential for cancer therapy. Cancer Res 2002;62:5749-54.

[44] Klein EA, Assoian RK. Transcriptional regulation of the cyclin D1 gene at a glance. J Cell Sci 2008;121:3853-7.

[45] Humtsoe JO, Kramer RH. Differential epidermal growth factor receptor signaling regulates anchorage-independent growth by modulation of the PI3K/AKT pathway. Oncogene 2010;29:1214-26.

[46] Lenferink AE, Busse D, Flanagan WM, Yakes FM, Arteaga CL. ErbB2/neu kinase modulates cellular p27(Kip1) and cyclin D1 through multiple signaling pathways. Cancer Res 2001;61:6583-91.

[47] Tao Y, Song X, Deng X, Xie D, Lee LM, Liu Y, et al. Nuclear accumulation of epidermal growth factor receptor and acceleration of G1/S stage by Epstein-Barr-encoded oncoprotein latent membrane protein 1. Exp Cell Res 2005;303:240-51.

[48] Wachsberger P, Burd R, Ryan A, Daskalakis C, Dicker AP. Combination of vandetanib, radiotherapy, and irinotecan in the LoVo human colorectal cancer xenograft model. Int J Radiat Oncol Biol Phys 2009;75:854-61.

[49] Hashimoto K, Man S, Xu P, Cruz-Munoz W, Tang T, Kumar R, et al. Potent preclinical impact of metronomic low-dose oral topotecan combined with the antiangiogenic drug pazopanib for the treatment of ovarian cancer. Mol Cancer Ther 2010;9:996-1006.

[50] Murakawa T, Tsuda H, Tanimoto T, Tanabe T, Kitahara S, Matsubara O. Expression of KIT, EGFR, HER-2 and tyrosine phosphorylation in undifferentiated thyroid carcinoma: implication for a new therapeutic approach. Pathol Int 2005;55:757-65.

[51] Carlomagno F, Santoro M. Identification of RET kinase inhibitors as potential new treatment for sporadic and inherited thyroid cancer. J Chemother 2004;16 Suppl 4:49-51. 
1

2

[52] Morisi R, Celano M, Tosi E, Schenone S, Navarra M, Ferretti E, et al. Growth inhibition of medullary thyroid carcinoma cells by pyrazolo-pyrimidine derivates. J Endocrinol Invest 2007;30:RC31-4.

[53] Celano M, Schenone S, Cosco D, Navarra M, Puxeddu E, Racanicchi L, et al. Cytotoxic effects of a novel pyrazolopyrimidine derivative entrapped in liposomes in anaplastic thyroid cancer cells in vitro and in xenograft tumors in vivo. Endocr Relat Cancer 2008;15:499-510. 
Table 1. Dose-reduction index (DRI) values for the drug combinations at $25 \%, 50 \%$ and $75 \%$ level of inhibition of HMVEC-d and $8305 \mathrm{C}$ cell proliferation.

\begin{tabular}{lcccccc}
\hline & \multicolumn{5}{c}{ DRI values } \\
\cline { 2 - 7 } Cells & $\mathbf{2 5 \%}$ & \multicolumn{2}{c}{$\mathbf{5 0 \%}$} & \multicolumn{2}{c}{$\mathbf{7 5 \%}$} \\
\cline { 2 - 7 } HMVEC-d & CLM3 & SN-38 & CLM3 & SN-38 & CLM3 & SN-38 \\
\hline $\mathbf{8 3 0 5 C}$ & 1.116 & 94.867 & 5.874 & 23.626 & 30.911 & 5.884 \\
\hline
\end{tabular}




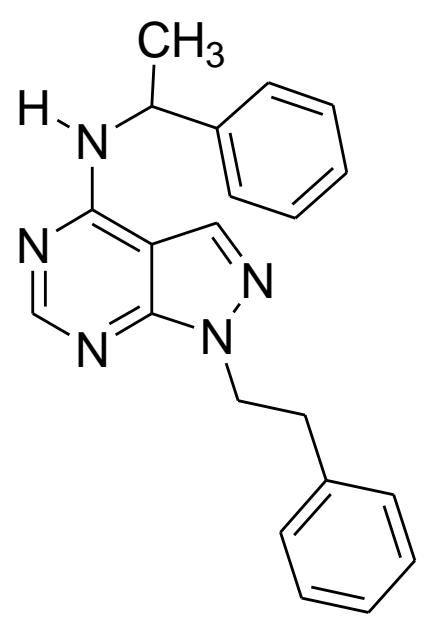

CLM3

Figure 1 

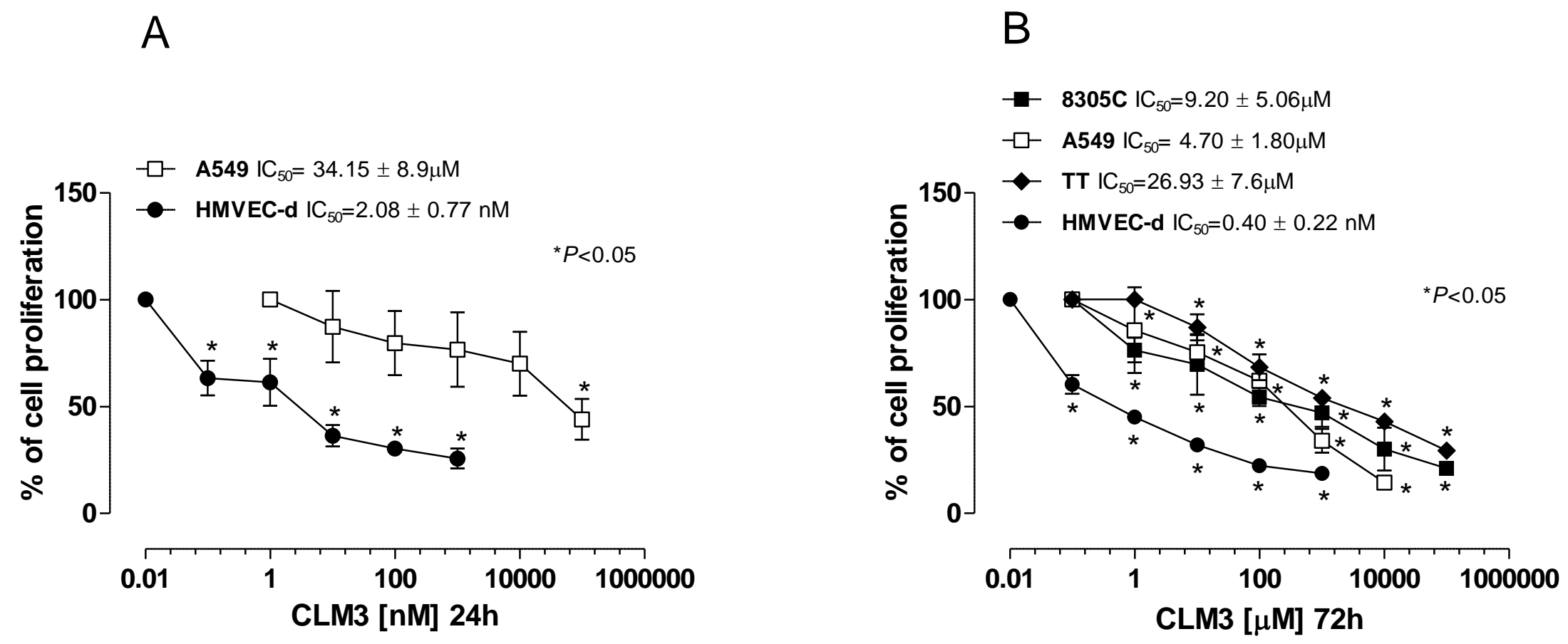

Figure 2 
A

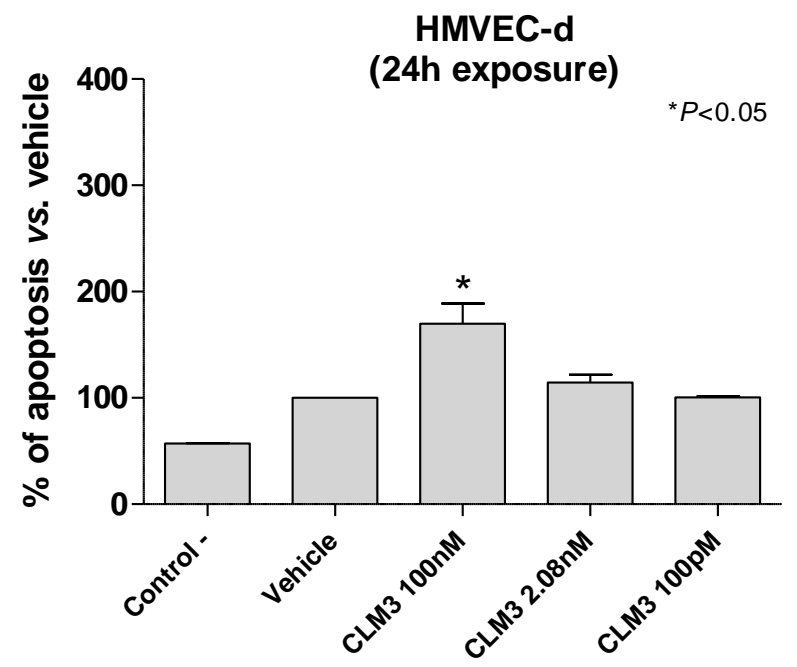

C

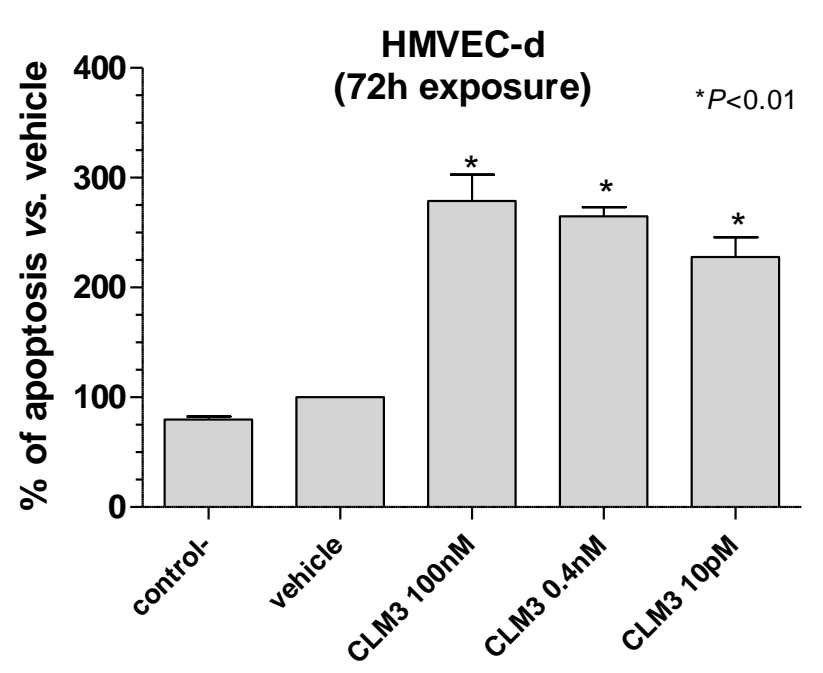

D
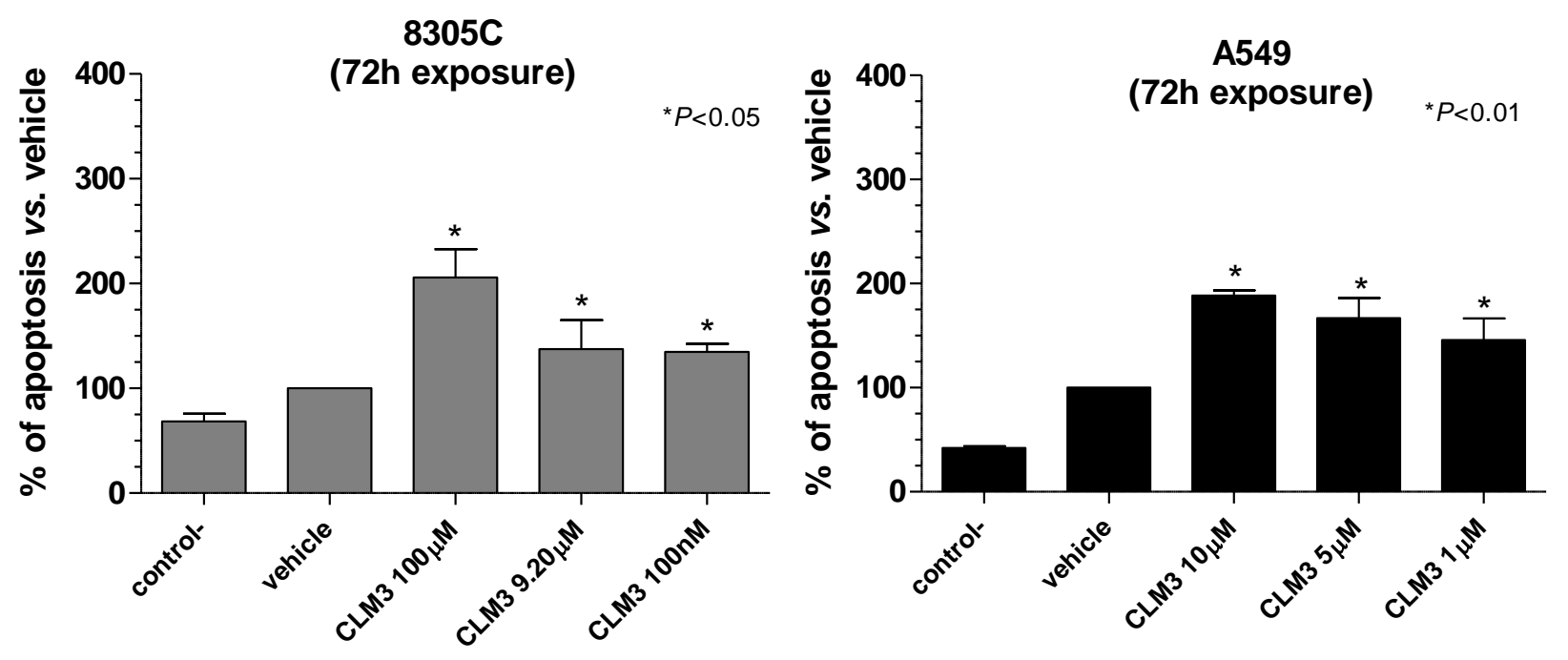

Figure 3 
A

\section{HMVEC-d}

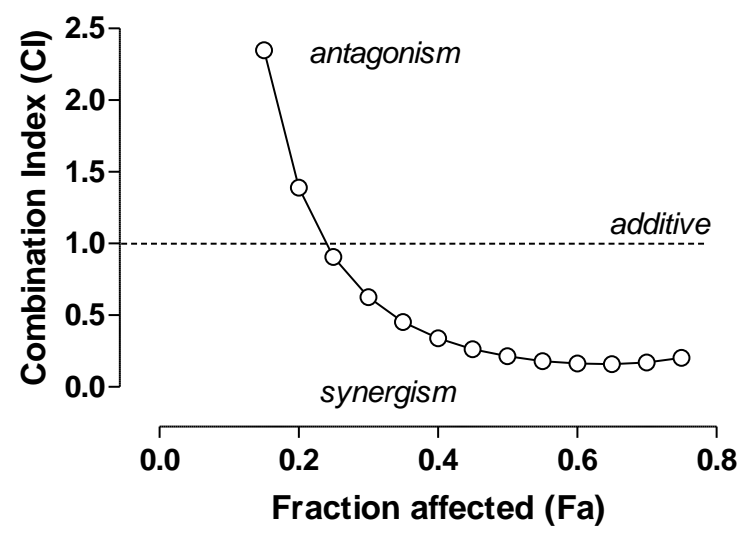

B

8305C

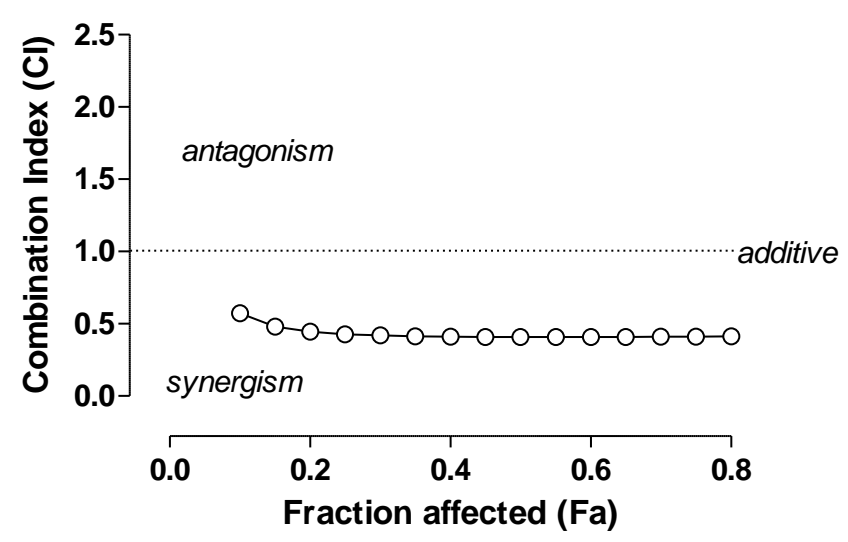


A

\section{HMVEC-d}

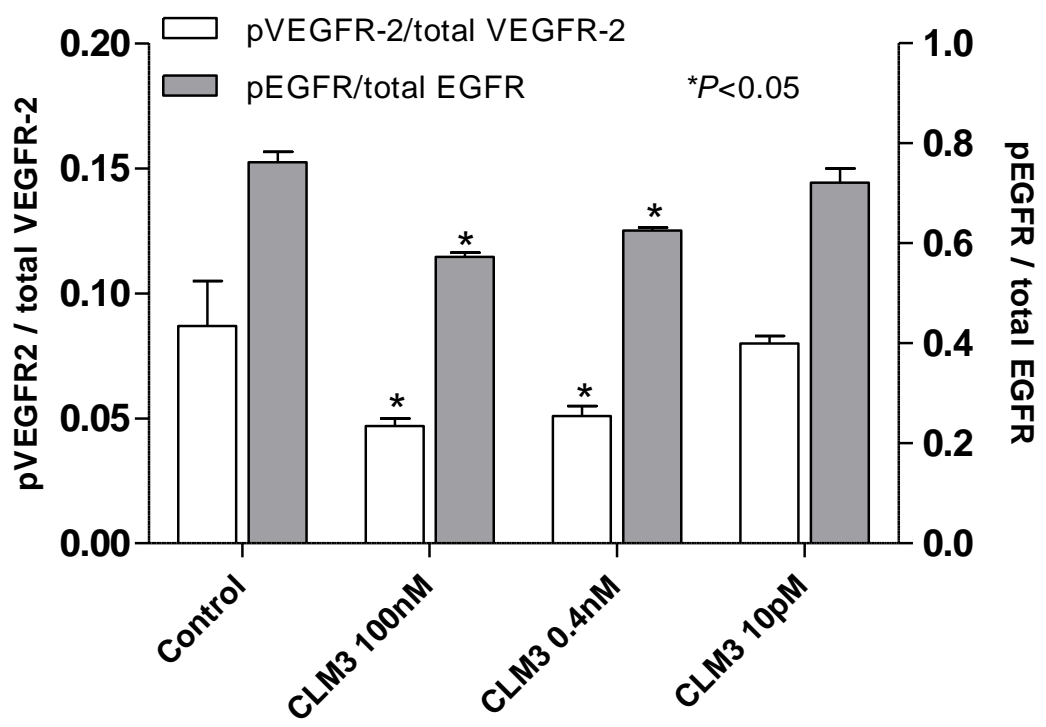

B

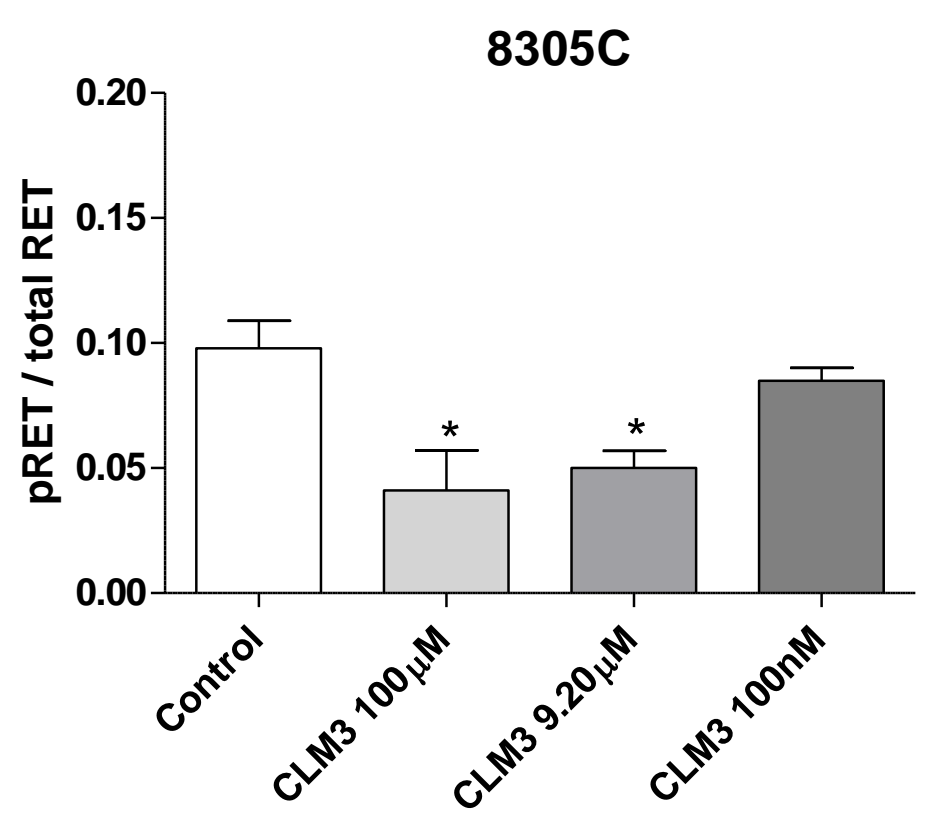

Figure 5 
A

HMVEC-d

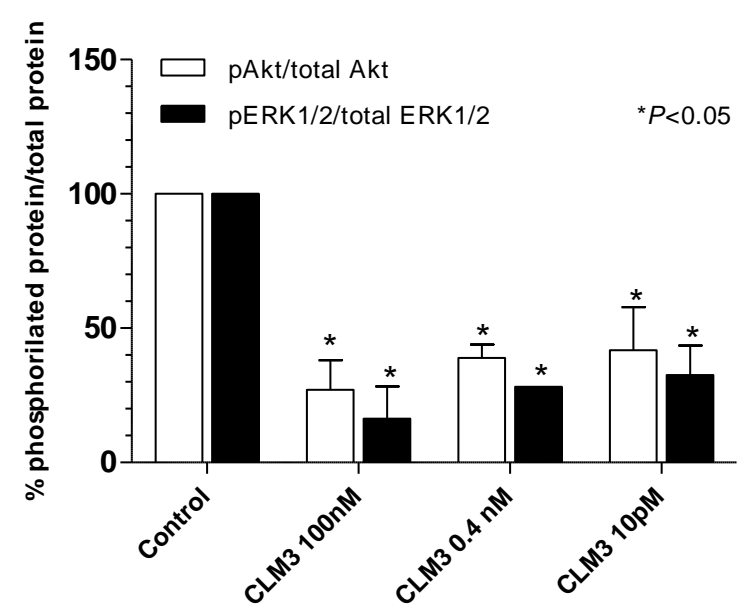

B

8305C

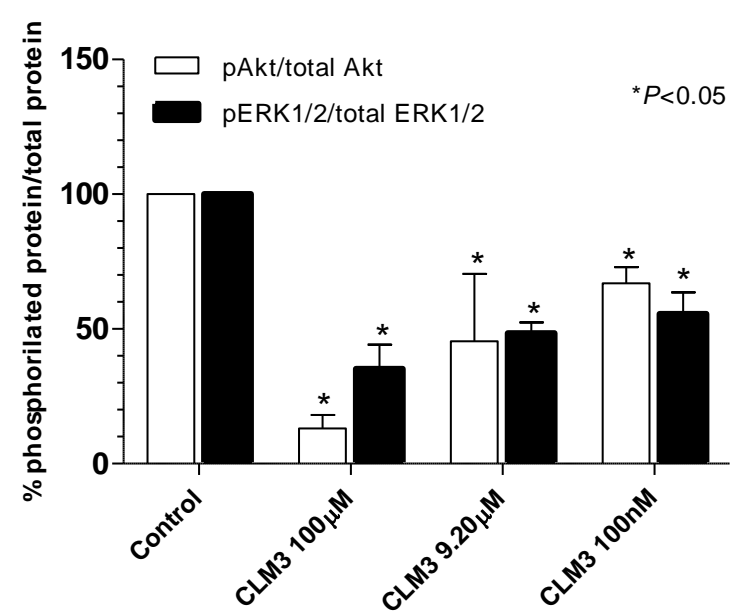

C

A549

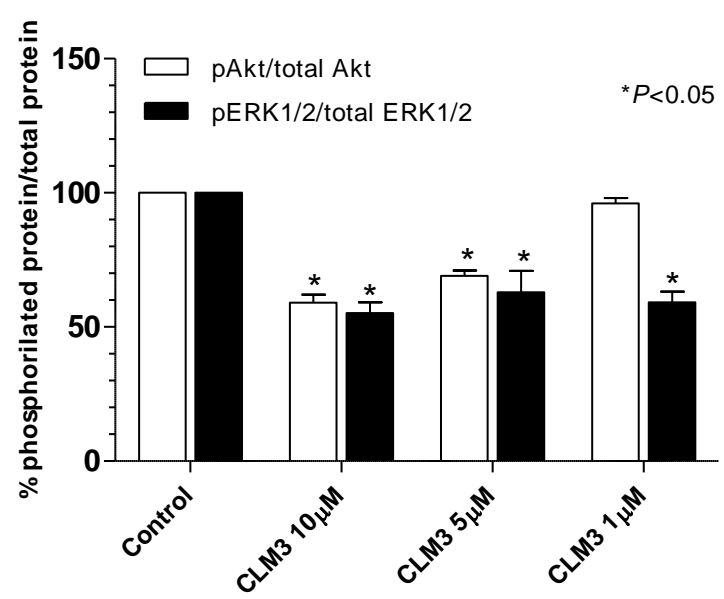



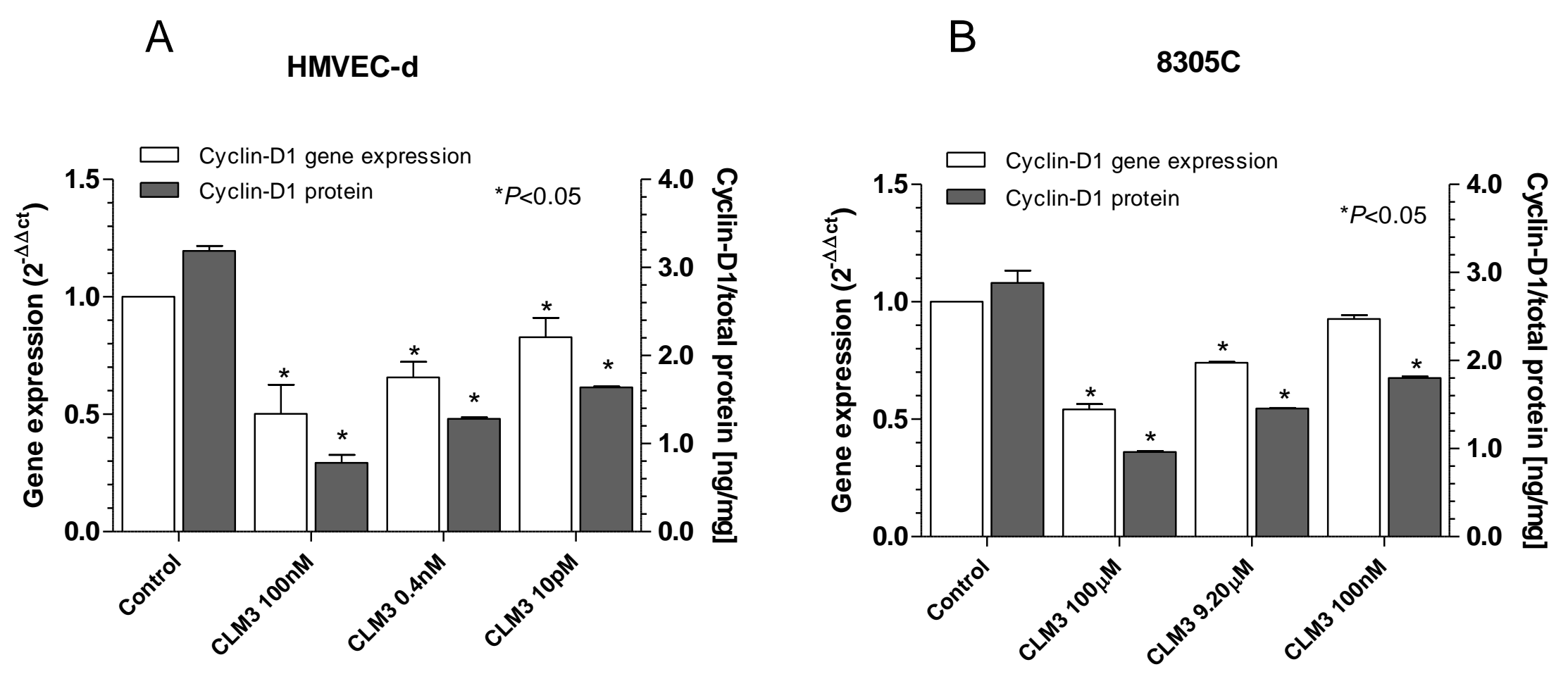

Figure 7 


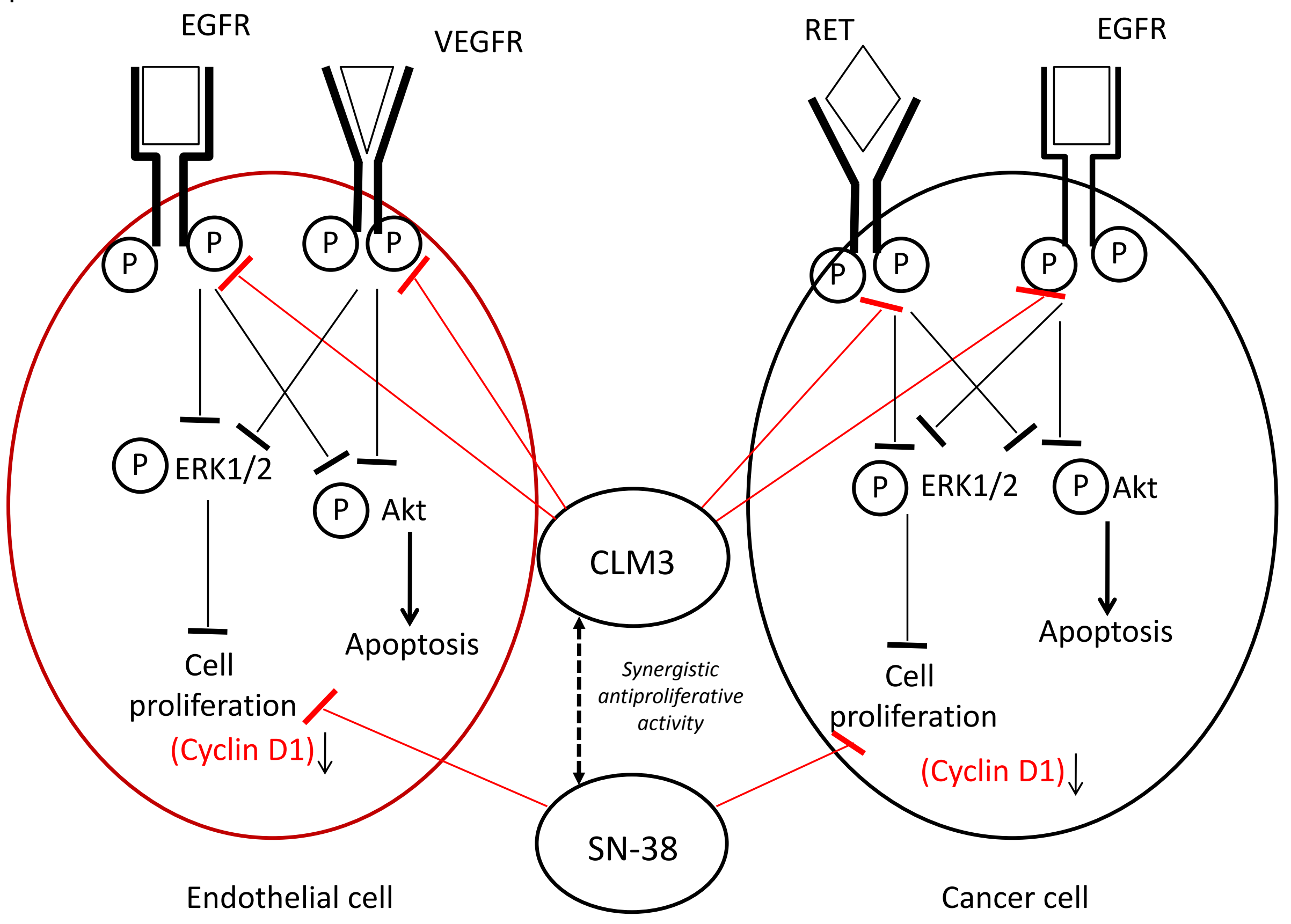

